\title{
Analysis of volatile compounds and antioxidant activity of the essential oil of oregano (Origanum vulgare L.)
}

\author{
Jose Tapiero ${ }^{1 *}$, Guillermo Salamanca ${ }^{2}$ and Carlos Marín ${ }^{3}$ \\ ${ }^{1}$ Servicio Nacional de Aprendizaje SENA, Universidad Nacional de Colombia \\ ${ }^{2}$ Universidad del Tolima. \\ ${ }^{3}$ Servicio Nacional de Aprendizaje SENA.
}

Accepted 8 May, 2019

\begin{abstract}
Aromatic plants make secondary metabolites that can be useful or toxic to an organism. In this work, we obtained Essential Oil (EO) by Microwave-assisted Hydrodistillation (MWHD). The process was carried out during the period from 15 min to 700 watts, with samples of 50, 100 and $200 \mathrm{~g}$, collected in Vijes and Sevilla, Valle, Colombia. For each sample of essential oil the relative density at $20^{\circ} \mathrm{C}$ and the Refractive Index were evaluated (RI). The chemical composition was evaluated using GC-MS and its antiradical activity (AA) was carried out using the $\mathrm{DPPH}^{*}, \mathrm{ABTS}^{+}$and ORAC methods. The process yield was between $0.087 \pm$ 0.012 and $0.140 \pm 0.005 \%$. Significant differences were observed for the RI with values between $1.475 \pm$ 0.001 and $1.484 \pm 0.003$ for a $(\mathrm{Pv}<0.05)$. The highest contributions correspond to $\mathrm{p}$-Cimeno (10.04), Terpinen-4-ol (9.48), Carvacrol (8.70\%) and Thymol (1.95\%) presented lowest values. The EO of oregano presents a good AA that ranges between $318.8 \pm 0.009$ to $320.6 \pm 0.003$ (Sevilla) and $310.8 \pm 0.021$ to $312.1 \pm 0.014$ (Vijes) mmol Trolox/100 g for $\mathrm{DPPH}^{*}$, and $23.852 \pm 0.018$ to $24.019 \pm 0.011$ (Sevilla) and $23.128 \pm 0.012$ to $23.412 \pm 0.009$ (Vijes) mmol Trolox/100 g for ABTS ${ }^{+}$. Finally, oregano essential oils presented low molecular weight aliphatic compounds, being markers of these matrices.
\end{abstract}

Keywords: Chromatography, microwave, antioxidant activity, natural products, aromatic plants.

*Corresponding author. Email: jtapiero@sena.edu.co. Tel: +57 3162701053.

\section{INTRODUCTION}

Oregano (Origanum vulgare L.) is a medicinal plant with digestive, carminative, antioxidant and expectorant properties (Albado et al., 2001; Ortega et al., 2016; Olmedo et al., 2014). Considered a strong antioxidant, capable of retarding or preventing the oxidation of molecules, that behaves as free radicals that initiate chain reactions damaging the cells (Castillo et al., 2007).

Essential Oils (EOs) are complex natural compounds; that present between 25 and 70 components with different concentrations and exhibit two or three main components with a concentration between 20 and $70 \%$ compared to the rest of the components (Meng et al., 2012; Pandey et al., 2014). These are liquid and volatile compounds distributed in all parts of the plants, which can be extracted by different procedures: steam drag, hydro-distillation assisted by microwaves and supercritical fluids among others (Márquez, 2011; Hossain et al., 2012). These can be alcohols, ketones, ethers, aldehydes that are produced and stored in the secretory channels of plants (Baldwin et al., 1999; Mariod, 2016).

Microwaves are electromagnetic radiation with frequencies between 0.3 and $300 \mathrm{GHz}$. Domestic and industrial equipment operates at $2.45 \mathrm{GHz}$ (Ferhat et al., 2006; Contreras, 2010). Due to their nature, they have electric and magnetic fields, which are perpendicular to each other (Contreras and Ruíz, 2012). The electric field is responsible for heating by bipolar rotation and ionic conduction, producing collisions with the surrounding molecules and allowing the release of thermal energy to the medium (León et al., 2015). When the extraction by Hydro-distillation Assisted by Radiation with Microwaves 
(MWHD) is used the heat produces the expansion and breakage of the cell walls facilitating the exit of the Essential Oil (EO) to the surrounding solvent (Pandey et al., 2014; Calvacante et al., 2016). The moisture content is fundamental in MWHD because the water heats more and promotes the release of the analytes to the surrounding environment ${ }^{11}$.

The analysis by Gas Chromatography coupled to Mass Spectroscopy (GC-MS) allows the identification of secondary metabolites present in EO, using comparative applications of NIST / EPA / NIH spectral mass libraries (Munhuweyi et al., 2018). In addition, it allows a qualitative analysis in a sample of $1 \mu \mathrm{l}$ and when a standard substance is available, the calibration curve can consolidate an exact quantitative analysis of the sample (Li et al., 2014).

Normally, EOs are composed mainly of terpene hydrocarbons (myrecene, pinene, terpinene, limonene, $\mathrm{p}$ cymene, $\alpha$ - and $\beta$-phellandrene) and (hydrocarbons containing oxygen) as acyclic monoterpene alcohols (geraniol, monocyclic alcohols (menthol, 4-carvomentol, terpineol, carveol, borneol), aliphatic aldehydes (citral, citronellal, perilaldehyde), aromatic phenols (carvacrol, thymol, safrole, eugenol), bicyclic alcohol (verbenol), monocyclic ketones, menthone, pulegone, carvone), monoterpene ketones bicyclic (thuonic, verbenone, fenchona), acids (citronelic acid, cinnamic acid) and esters (linalyl acetate) (Zeng et al., 2016; Mariod, 2016). The constituents of mono and essential oils are formed by condensation of isopentenyl pyrophosphate units (Mariod, 2016).

The oregano EO has a volatile fraction that is formed by hydrocarbons, sesquiterpenes and oxygenated derivatives such as aldehyde, alcohols, esters, oxides and aliphatics (Vaioa et al., 2010). In the Essential Oil of Oregano (EOO) flavonoids have been identified as Apigenin and Luteolin, aliphatic alcohols, terpenic compounds and derivatives of phenylpropane (Acevedo et al., 2013). Coumérico, Ferulic acids have also been found, Caffeic, Hydroxybenzoic and Vanillinic (Naeini et al., 2010).

The subspecies Oreganum vulgare ssp. Hirtum has been studied, in relation to the quality of its essential oil (Albado et al., 2001). And the main components of this species are carvacrol and thymol originated by specific enzymes that direct their biosynthesis (Castillo et al., 2007; Amadio and Miralles, 2011). Generally, these two compounds are between $75.23 \pm 0.004$ and $78.14 \pm$ $0.008 \%$, which varies according to the bioclimatic conditions and the environment surrounding the crop (Naeini et al., 2010; Amadio and Miralles, 2011; Tapiero et al., 2016).

The yield of the essential oil in the dry leaf varies between 2 and 6\% (Ferhat et al., 2006). This percentage is affected by the altitude of the place of cultivation (Acevedo et al., 2013), and by the time of collection (Ali et al., 2015; Torrenengra, 2014).
Worldwide, a large number of species are recognized by the name of oregano; the characteristic genus is Origanum, although the Spanish oregano (Coridohymus capitatus L.) and the Mexican oregano (Limpia graveolens Kunth) are also recognized. In Argentina, the species Origanum majorana $\mathrm{L}$. and $O$. vulgare $\mathrm{L}$. and their hybrids, $O$. majoricum and $O$. applii, are recognized. Currently, many spices and herbs, particularly of the Lamiaceae family, to which oregano belongs and which have been evaluated as antioxidants and food preservatives, thus increasing its importance in the industry as an alternative to synthetic additives (Castillo et al., 2007; Amadio and Miralles, 2011).

In oregano monoterpenic hydrocarbons, Terpinene and r-Cymene are frequent components, sometimes at low concentrations (Munhuweyi et al., 2018; Torrenengra, 2014; Dutra et al., 2019). In Colombia (Acevedo et al., 2013; Silva-Flores et al., 2017), they have characterized three groups of mountain oregano present in relation to the composition of essential oils. A chemotype A rich in terpenes (monoterpenes and sesquiterpenes representing 45 and $27 \%$, respectively), a second chemotype $\mathrm{B}$, whose main components are Carvacrol $(40 \%)$, p-Cymene (13\%), g-Terpinene $(11 \%)$ and Thymol $(11 \%)$; These values are similar to those observed in samples from Brazil ${ }^{18,28}$. A third $C$ chemotype has high levels of Thymol (56), p-Cymene (9\%) and g-Terpinene $(5 \%)$. This chemotype is similar to those reported in Venezuela (Amadio and Miralles, 2011; Leyva et al., 2007). It is worth indicating that, has carried out studies of a chemotype recognized as French oregano, (Plectranthus amboinicus (Lour.) Spreng), on the Colombian Atlantic coast (León et al., 2015; Ali et al., 2015).

Antioxidants are substances that inhibit the cellular oxidation induced by toxins such as free radicals (Acosta and Carreño, 2011). These can come from natural digestion, the metabolism of food, environmental conditions, consumption of medicines and alcohol, among others (Harlen and Jati, 2018; Bajalan et al., 2017); causing oxidative damage to proteins, lipids, enzymes and DNA (Acosta and Carreño, 2011). Living cells have a good scavenging mechanism to avoid excess cell damage caused by free radicals (Harlen and Jati, 2018). However, with aging and external causes, these mechanisms become inefficient, requiring dietary supplementation of antioxidants. Under this condition, aromatic plants, especially their AEs, are being evaluated for their antioxidant activity (Muñoz et al., 2009).

The antioxidant activity was evaluated for the stable free radical $\mathrm{DPPH}^{*}$ that oxidized and decolorized in the presence of two types of oregano (Origanum appli and Origanum majoricum) from the city of Mendoza, Argentina; where the Origanum application presented greater sequestration power than $O$. majoricum for dilutions in low concentrations. At higher concentrations, no significant differences were found between them 
(Amadio and Miralles, 2011; Asensio, 2013).

The production of $A E$ focuses on countries that have large areas. According to the World Health Organization (WHO) and the Food and Agriculture Organization of the United Nations (FAO), it is estimated that of the $2 / 3$ of the population of our planet, 4 billion people turn to this type of products for their food and to cure their psychophysical ailments, turning the product into a high development potential for our country.

The objective of this research was to extract by microwave-assisted hydro-distillation (MWHD) essential oil of oregano (Origanum vulgare L.) from the municipalities of Sevilla and Vijes, Valle del Cauca, to characterize its physicochemical properties, to assess its chemical composition by chromatography of gases-mass spectrometry (GC-MS) and to evaluate its antioxidant activity against the $\mathrm{DPPH}^{*}, \mathrm{ABTS}^{+}$and ORAC methods.

\section{MATERIALS AND METHODS}

\section{Plant material}

For the extraction of the essential oil, fresh leaves of oregano from the municipalities of Vijes and Sevilla Valle del Cauca were used; geographically located between 987 and 1612 m.s.n.m with an average temperature of $25^{\circ} \mathrm{C}$ and relative humidities of 70 to $75 \%$ respectively.

\section{Microwave-assisted hydro-distillation of essential oils}

The EO of the vegetable matrices were obtained by hydrodistillation radiated by microwaves (MWHD). A modified Clevenger kit with a capacity of $500 \mathrm{~g}$ of sample was used. Distillation was performed using 50 to 100 samples and $200 \mathrm{~g}$ of fresh leaves for 45 minutes in three 15" cycles at a power of 700 watts. The extracted fractions were stored in amber vials at $4^{\circ} \mathrm{C}$.

\section{Physicochemical evaluation of oregano essential oil}

The physicochemical properties of the $\mathrm{AE}$ were analyzed in terms of density according to the method described in ISO (279: 1983), solubility in ethanol considering ISO Standard 875: 1999 and refractive index carried out with a thermostated bath refractometer according to the Standard ISO (280: 1998). The analyses were performed in triplicate for each of the samples obtained.

\section{Chromatographic analysis of oregano essential oil}

Samples were prepared by dissolving $50 \mu \mathrm{l}$ of $\mathrm{AE}$ and $1.0 \mu \mathrm{l}$ of internal standard of (n-tetradecane) in dichloromethane to a final volume of $1.0 \mathrm{ml}$. The characterization was carried out by gas chromatography coupled to mass spectrometry (GC-MS). The recognition of the components of the oils was carried out in a gas chromatograph (BRUKER $450 \mathrm{GC}$ ), using a BR-5ms column (30 m $\times 0.25 \mathrm{~m}, 0.25 \mu \mathrm{m})$ and Helium at a concentration of $1 \mathrm{ml} / \mathrm{min}$ as the entraining gas. A triple quadruple mass detector (BRUKER 320) was used based on the retention rates of Kovats and for its calculations the retention times were considered by means of a calibration curve of hydrocarbon standards from $\mathrm{C} 10$ to $\mathrm{C} 25$ run at the same operational conditions for the extracted EOs.

\section{Antioxidant activity of oregano essential oil}

To determine the antioxidant capacity of the EAs, the methodologies standardized by (35) for $\mathrm{DPPH}^{*}$ and $\mathrm{ABTS}^{+}$. Where, $75 \mu \mathrm{l}$ of sample were taken and added to $150 \mu \mathrm{l}$ of a methanolic solution of $\mathrm{DPPH}^{*}(100 \mathrm{ppm})$ which were incubated at room temperature for 30 minutes. The sample absorbance was determined by spectrophotometry techniques at $550 \mathrm{~nm}$ in a Thermo Scientific UV-Visible Evolution spectrophotometer. Ascorbic acid $(25 \mu \mathrm{g} / \mathrm{ml})$ as a positive control of uptake of $\mathrm{DPPH}^{*}$ radicals was used. The antioxidant activity against of the free radical $\mathrm{ABTS}^{+}$ was determined using the method described by Prior et al., 2005 with some modifications. The ABTS ${ }^{+}$radical will be formed after the reaction of $3.5 \mathrm{~mm}$ ABTS with $1.25 \mathrm{~mm}$ potassium persulfate (final concentration). The ORAC method measures the ability of antioxidants in the sample to protect the protein from oxidative damage (Prior et al., 2005). Fluorescence is used as a protein and the mechanism of the reaction is based on the transfer of a hydrogen atom from the antioxidant to the free radical and analyzed for lipophilic ORAC.

\section{RESULTS AND DISCUSSION}

In the process of microwave-assisted extraction, transparent characteristic aroma oils are obtained, with an unctuous aspect soluble in ethanol, chloroform, ethyl ether and slightly soluble in water (Mechergui et al., 2016). The refractive index of the matrices studied was between 1.475 and 1.486, the yield of the process of time-dependent, the power and the amount of sample. Table 1 and Figure 1 show the relationship between the volume of oil extracted at constant power and weights between 50 and $200 \mathrm{~g}$ of leaves, with significant differences between treatments $(\mathrm{Pv}<0.05)$.

As regards performance, significant differences were found between the extraction times for the MWHD method, this is due to the structural deterioration of the components present in the EO caused by the electromagnetic radiation used during the extraction. On the other hand, the heating generated by microwaves is homogeneous and at an accelerated rate compared to heating by conduction (Ferhat et al., 2006). However, it is important to consider cultivation methods and geobotanical conditions such as altitude, climate, temperature, soil, lightness, and rainfall, time of harvest and age of the plant.

The EOs presented significant differences for the refractive index parameter. These were between $1.475 \pm$ 0.001 and $1.484 \pm 0.003$ for one $(\mathrm{Pv}<0.05)$, being an important measure in the determination of the quality due to the fact that it allows to control any type of adulteration because it is an exclusive parameter for each EO (Mejía, 2015). The optical activity is a value that changes in the EOs according to the bioclimatic conditions, environment and type of extraction, but at the same time, it is a very fixed quantity for each type of oil that establishes if this has been mixed with other matrices (Pandey et al., 2014).

The works related to the composition of the essential oil 
Table 1. Average values observed in some parameters in relation to the MWHD for the oregano EO in the areas of Seville and Vijes Valle del Cauca.

\begin{tabular}{lccccccc}
\hline Geographical area & $\begin{array}{c}\text { Power } \\
(\text { Watt) }\end{array}$ & $\mathbf{n}$ & Mass $(\mathbf{g})$ & Volume $(\mathbf{m l})$ & Density $\left(\mathbf{g ~ m l ~}^{-1}\right)$ & IR & Process yield (\%) \\
\hline \multirow{3}{*}{ Sevilla } & 700 & 3 & 50 & $0.04 \pm 0.01$ & $0.917 \pm 0.007$ & $1.477 \pm 0.002$ & $0.087 \pm 0.012$ \\
& 700 & 3 & 100 & $0.10 \pm 0.02$ & $0.913 \pm 0.001$ & $1.475 \pm 0.001$ & $0.100 \pm 0.017$ \\
& 700 & 3 & 200 & $0.22 \pm 0.12$ & $0.913 \pm 0.001$ & $1.478 \pm 0.002$ & $0.112 \pm 0.008$ \\
& & & & & & & \\
Vijes & 700 & 3 & 50 & $0.05 \pm 0.010$ & $0.914 \pm 0.001$ & $1.484 \pm 0.003$ & $0.100 \pm 0.020$ \\
& 700 & 3 & 100 & $0.10 \pm 0.032$ & $0.912 \pm 0.001$ & $1.484 \pm 0.002$ & $0.103 \pm 0.032$ \\
& 700 & 3 & 200 & $0.28 \pm 0.010$ & $0.913 \pm 0.001$ & $1.483 \pm 0.002$ & $0.140 \pm 0.005$ \\
\hline
\end{tabular}

Note: extraction time of 45 minutes in three 15 -minute cycles.

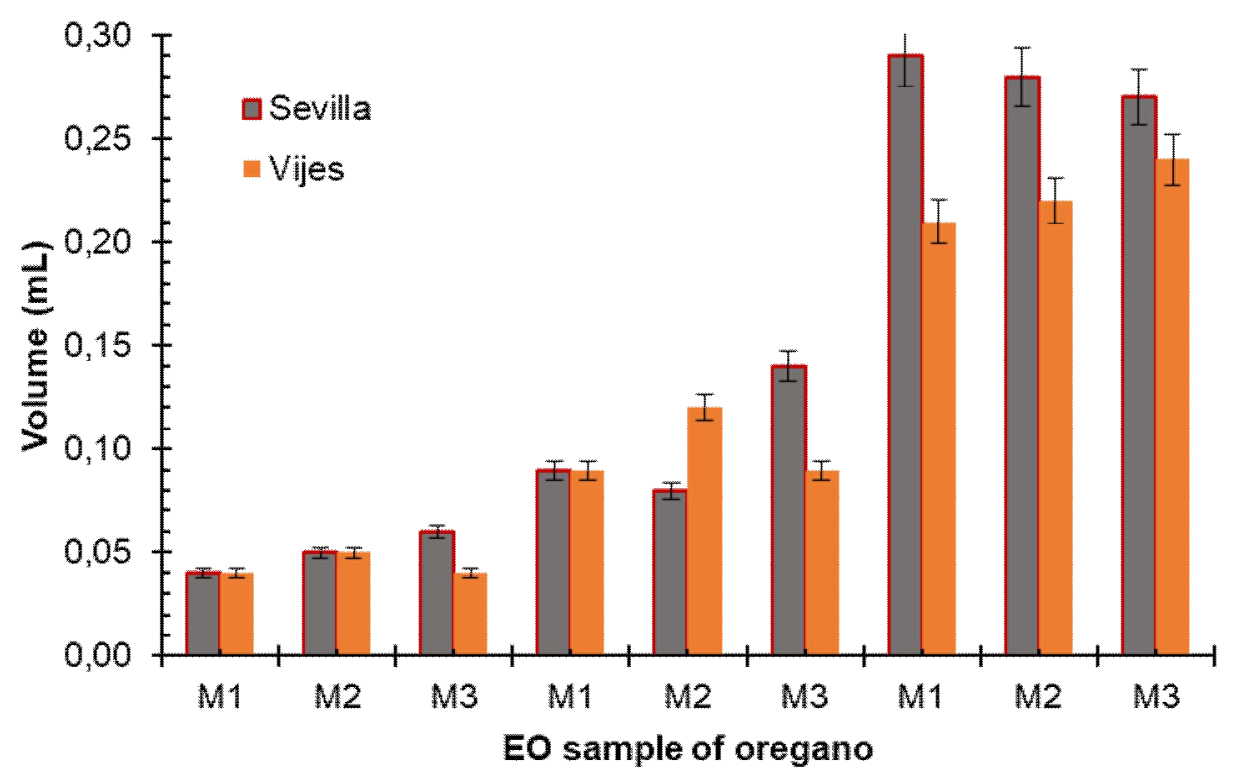

Figure 1. Evolution of the extraction process of essential oil from Oregano by MWHD.

of oregano show great variability (Stefanovic et al., 2015). It depends mainly on the part of the plant that is distilled and the species or subspecies. In all cases, thymol and Carvacrol coincide as the majority compounds. In addition, it has been observed that in Origanum vulgare the high content of polyphenolic compounds has been proven, which provide effective protection in all phases of lipid oxidation (Amadio and Miralles, 2011; Muñoz et al., 2009).

In Table 2, the main constituents of oregano essential oil are listed, with 20 compounds distributed in a ketone, an epoxide, seven alcohols and eleven cyclic hydrocarbons (Figure 2). These same components have been reported in other research works (Acevedo et al., 2013; Amadio and Miralles, 2011) with similar values. Dihydrocarvone and cariophylene oxide have low concentrations, while the highest contributions correspond to p-cymene (10.1\%), terpinene-4-ol (9.48\%), carvacrol $(8.90 \%)$ and thymol (1.95\%) proper to the botanical family. The presence of these metabolites coincides with the report of Silva-Flores et al. (2017), Acevedo et al. (2013), Acosta and Carreño (2011) and Tapiero et al. (2016).

During the antioxidant evaluation of a food product, the interactions that occur between the compounds with the different mechanisms of action are considered (Omar et al., 2012). For this reason, it is necessary to evaluate its capacity through different methods according to its root source. Antioxidants can act by several mechanisms and their results are expressed as an antiradical activity $\mathrm{IC}_{50}$ (effective concentration 50) known as the amount of antioxidant that decreases radical absorption to $50 \%$ of the initial amount.

The effective concentration $\left(\mathrm{IC}_{50}\right)$ measures the uptake capacity of the $\mathrm{ABTS}^{+}$or $\mathrm{DPPH}^{*}$ radicals of the EO against an antioxidant standard such as ascorbic acid, 
Table 2. Volatile components present in the Oregano EO extracted by microwaves.

\begin{tabular}{|c|c|c|c|c|c|c|c|c|}
\hline Function & Compound & RT (min) & IK & $\% \mathrm{Ppm}$ & Compound & RT (min) & IK & $\%$ ppm \\
\hline \multirow{4}{*}{ Alcohol } & Terpinen-4-ol & 11.44 & 1628 & 9.48 & T-Muurolol & 17.56 & 2148 & 0.15 \\
\hline & L- $\alpha$-Terpineol & 11.63 & 1634 & 2.81 & a-Cadinol & 17.70 & 1652 & 0.12 \\
\hline & Thymol & 12.94 & 2120 & 1.95 & Carvacrol & 13.06 & 1299 & 8.90 \\
\hline & (-)-Espatulenol & 16.80 & 1578 & 0.05 & - & - & & - \\
\hline \multirow{2}{*}{$\begin{array}{l}\text { Ketone } \\
\text { Epoxide }\end{array}$} & Dihydrocarvone & 11.66 & 1748 & 0.09 & - & - & & - \\
\hline & O. Cariofilene & 16.90 & 1561 & 0.13 & - & - & & - \\
\hline \multirow{6}{*}{$\mathrm{CH}$} & a-Felandrene & 8.61 & 1146 & 1.76 & Cariofilene & 14.84 & 1658 & 1.38 \\
\hline & $\alpha$-Terpinene & 8.78 & 1258 & 0.50 & $\beta$-Copaene & 14.96 & 1389 & 0.05 \\
\hline & p-Cymene & 8.92 & 1248 & 10.1 & $\beta$-Bisabolene & 15.87 & 1726 & 0.13 \\
\hline & D-Limonene & 8.99 & 1212 & 2.54 & Humulene & 15.31 & 1608 & 0.09 \\
\hline & Y-Terpinene & 9.47 & 1078 & 4.52 & Naphthalene & 16.03 & 1179 & 0.07 \\
\hline & B-Bourbonene & 14.35 & 1388 & 0.31 & & & & \\
\hline
\end{tabular}

CH: Cyclic Hydrocarbon; RT: Retention Time - Column: BR-5 ms (30 m × 0.25 m, $0.25 \mu \mathrm{m})$.

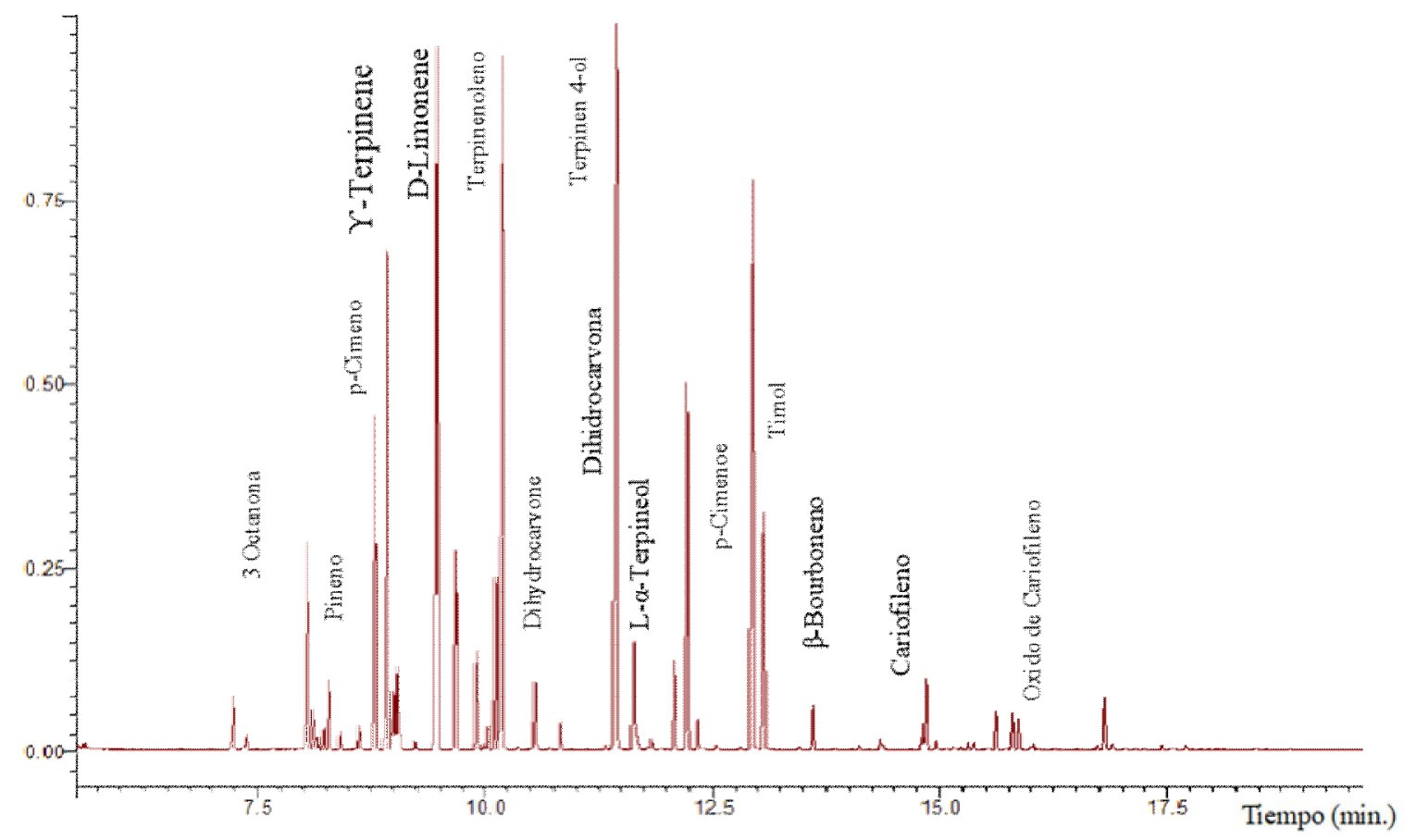

Figure 2. Chromatogram characteristic of the oregano essential oil extracted with the assistance of a microwave system.

which yields a hydrogen, generating a transfer of double bond electrons, up to oxygen, which suffered the loss of the hydrogen atom until the energy balance was established. Where, the ascorbic acid finally yields two hydrogens.

The antioxidant activity for the working concentrations $(5,10$ and 40$) \mu \mathrm{g} / \mathrm{ml}$ was between $318.8 \pm 0.009$ to 320.6 \pm 0.003 (Seville) and $310.8 \pm 0.021$ to $312.1 \pm 0.014$ (Vijes) mmol Trolox/100 $\mathrm{g}$ for $\mathrm{DPPH}^{*}$, and $23.852 \pm 0.018$ to $24.019 \pm 0.011$ (Seville) and $23.128 \pm 0.012$ to 23.412 \pm 0.009 (Vijes) mmol Trolox/100 $\mathrm{g}$ for $\mathrm{ABTS}^{+}$(Table 3). It is possible to conclude that the extraction time influences the types of compounds in the mixture, which determine their antiradical capacity.

The antioxidant activity for the EO oregano (O. vulgare L.) obtained by MWHD by the lipophilic ORAC value was $0.3072 \pm 0.006-0.3256 \pm 0.004 \mathrm{mmol}$ Trolox $/ 100 \mathrm{~g}$ and $0.3014 \pm 0.012$ to $0.3056 \pm 0.010 \mathrm{mmol}$ Trolox $/ 100 \mathrm{~g}$ for 
Table 3. Antiradical activity of EOs of oregano from two Colombian locations.

\begin{tabular}{lcccc}
\hline Sample & $\begin{array}{c}\text { Concentration } \\
(\boldsymbol{\mu} \mathbf{g} / \mathbf{m l})\end{array}$ & $\begin{array}{c}\text { DPPH }^{*} \\
(\mathbf{m m o l} \text { Trolox/100 } \mathbf{g})\end{array}$ & $\begin{array}{c}\text { ABTS }^{+} \\
(\mathbf{m m o l} \text { Trolox/100 } \mathbf{~})\end{array}$ & $\begin{array}{c}\text { ORAC Lipophilic } \\
(\mathbf{m m o l} \text { Trolox/100 } \mathbf{~})\end{array}$ \\
\hline \multirow{3}{*}{ Sevilla } & 5 & $318.8 \pm 0.009$ & $24.019 \pm 0.011$ & $0.3256 \pm 0.004$ \\
& 10 & $319.4 \pm 0.012$ & $23.912 \pm 0.009$ & $0.3072 \pm 0.006$ \\
& 40 & $320.6 \pm 0.003$ & $23.852 \pm 0.018$ & $0.3201 \pm 0.008$ \\
Vijes & 5 & $310.8 \pm 0.021$ & & \\
& 10 & $312.1 \pm 0.014$ & $23.412 \pm 0.009$ & $0.3023 \pm 0.011$ \\
& 40 & $311.4 \pm 0.035$ & $23.128 \pm 0.012$ & $0.3056 \pm 0.010$ \\
& & $23.181 \pm 0.011$ & $0.3014 \pm 0.012$ \\
\hline
\end{tabular}

*The data are expressed in mmol Trolox / $100 \mathrm{~g}$ - Antioxidant power of 2, 2'-Azinobis-3-ethylbenzthiazoline-6-sulonic acid (ABTS), of 2,2-diphenyl-1-picrilhydrazil (DPPH) and Oxygen radical absorption capacity (ORAC); Equivalent of Trolox (ET).

the samples obtained in Seville and Vijes, respectively. Showing that this EO has a high capacity to inhibit the discoloration of the fluorescein molecule (Amadio and Miralles, 2011; Boskovic et al., 2015).

\section{CONCLUSION}

Microwave-assisted hydro-distillation (MWHD) is a method of extracting essential oils with broad advantages over the traditional method. It is a process that does not require high water consumption and without solvents, with shorter process times (three times of $15 \mathrm{~min}$ at a power of 700 watts) and good yields (0.087 to $0.140 \%)$. Chromatographic analyzes expose p-Cymene (10.1\%), terpinen-4-ol $(9.48 \%)$, carvacrol $(8.90 \%)$ and thymol $(1.95 \%)$ as the main components of the samples evaluated. The antiradical capacity of the EO of oregano showed good antioxidant activity for each of the methods analyzed; evidencing that it is a product to be taken into account for the incorporation in agro-industrial products and in edible films and coatings for food.

\section{REFERENCES}

Acevedo D, Navarro M, Monroy L, 2013. Chemical composition of essential oil of oregano leaves (Origanum vulgare). Inf Tecnol, 24(4): 43-48.

Acosta RA, Carreño BLM, 2011. Comparative Study of Extracts and Essential Oils of Lippia origanoides H.B.K., Zingiber officinale and Rosmarinus officinalis L., as Antioxidant Agents in Compact Powders. Universidad Inndustrial de Santander.

Albado E, Saez G, Ataucusi G, 2001. Composición química y actividad antibacteriana del aceite esencial del Origanum vulgare (orégano). Rev Médica Hered, 12(3): 16-19.

Ali B, Al-Wabel NA, Shams S, Ahamad A, Khan SA, Anwar F, 2015. Essential oils used in aromatherapy: A systemic review. Asian Pac J Trop Biomed; 5(8): 601-611.

Amadio C, Miralles S, 2011. Origanum essential oil: a potential food additive. pp: 237-245

Asensio CM, 2013. Varieties of oregano as an antimicrobial preservative, antioxidant and the sensory properties of foods: cottage cheese, ricotta and olive oil.

Bajalan I, Rouzbahani R, Pirbalouti AG, Maggi F, 2017. Industrial crops \& products antioxidant and antibacterial activities of the essential oils obtained from seven Iranian populations of Rosmarinus officinalis. Ind Crop Prod, 107: 305-311.

Baldwin E, Burns JK, Kazokas W, Brecht JK, Hagenmaier RD, Bende RJ, Pesis E, 1999. Effect of two edible coatings with different permeability characteristics on mango (Mangifera indica L.) ripening during storage. Postharvest Biol Technol, 17(3): 215-226.

Boskovic M, Zdravkovic N, Ivanovic J, Janjic J, Djordjevic J, Starcevic M, Baltic MZ, 2015. Antimicrobial activity of thyme (Tymus vulgaris) and oregano (Origanum vulgare) essential oils against some foodborne microorganisms. Procedia Food Sci, 5: 18-21.

Calvacante A, Alves de Souza MR, Barros ST, Bruno NV, Ferreira MSL, Gonçalves ÉCBA, 2016. Development and evaluation of biodegradable films and coatings obtained from fruit and vegetable residues applied to fresh-cut carrot (Daucus carota L.). Postharvest Biol Technol, 112: 194-204.

Castillo GA, García JA, Estarrón M, 2007. Extraction method that enriches phenolic content in oregano (Lippia graveolens H.B.K.) essential oil. J Food Process Eng, 30(6): 661-699.

Contreras P, Ruíz P, 2012. Comparative study of two extraction methods for the essential oil present in the grapefruit peel (Citrus maxima). Universidad de Cartagena - Bólivar - Colombia.

Contreras VH, 2010. Y Bioquímica. p. 34.

Dutra TV, Castro JC, Menezes JL, Ramos TR, Nunes do Prado I, Machinski Jr M, Graton JM, Filho MBA, 2019. Bioactivity of oregano (Origanum vulgare) essential oil against Alicyclobacillus spp. Ind Crops Prod; 129: 345-349.

Ferhat MA, Meklati BY, Smadja J, Chemat F, 2006. An improved microwave Clevenger apparatus for distillation of essential oils from orange peel. J Chromatogr A; 1112 (1-2): 121-126.

Harlen WC, Jati IRAP, 2018. Antioxidant Activity of Anthocyanins in Common Legume Grains. Polyphenols: Mechanisms of Action in Human Health and Disease. Elsevier Inc., Ansterdam.

Hossain MA, Al-Hashmi RA, Weli AM, Al-Riyami Q, Al-Sabahib JN, 2012. Constituents of the essential oil from different brands of Syzigium caryophyllatum L. by gas chromatography-mass spectrometry. Asian Pac J Trop Biomed, 2(3 SUPPL.): S1446-9.

León MG, Osorio FMR, Martínez USR, 2015. Comparison of two methods for extraction of essential oil from Citrus sinensis L. Rev Cuba Farm, 49(4): 742-750.

Leyva MA, Ferrada PJ, Martínez JR, Stashenko EE, 2007. Performance and chemical composition of the essential oil of Zingiber officinale based on the particle diameter. Sci Technol, 13(33):187188.

Li XL, Meng DL, Zhao J, Yang YL, 2014. Extraction using AEO-9 determination of synthetic phenolic antioxidants in essence perfume by high performance liquid chromatography with vortex-assisted, cloud-point. Chinese Chem Lett, 25(8): 1198-1202.

Mariod AA, 2016. Effect of Essential Oils on Organoleptic (Smell, Taste, and Texture) Properties of Food. Essential Oils in Food Preservation, Flavor and Safety; 131-137.

Márquez SD, 2011. Evaluation of the yield in the obtaining of the oil "Piper auritum kunth" by means of hydrodynamilation assisted by 
miicroondas. Universidad Veracruzana - Veracruz - México.

Mechergui K, Jaouadi W, Coelho JP, Khouja ML, 2016. Effect of harvest year on production, chemical composition and antioxidant activities of essential oil of oregano (Origanum vulgare subsp glandulosum (Desf.) letswaart) growing in North Africa. Ind Crops Prod, 90: 32-37.

Mejía NF, 2015. Extraction of rosemary essential oil (Rosmarinus officinalis). Arequipa, Peru. Arequipa - Perú. (Oils and Fats Technology).

Meng J, Chen X, Yang W, Song J, 2012. Gas chromatography-mass spectrometry analysis of essential oils from five parts of Chaihu (Radix Bupleuri Chinensis). J Tradit Chinese Med, 34(6): 741-748.

Munhuweyi K, Caleb OJ, van Reenen AJ, Opara UL, 2018. Physical and antifungal properties of $\beta$-cyclodextrin microcapsules and nanofibre films containing cinnamon and oregano essential oils. LWT - Food Sci Technol, 87: 413-422.

Muñoz A, Kouznetsov V, Stashenko E, 2009. Composition and in-vitro antioxidant capacity of essential oils rich in Thymol, Carvacrol, transAnethole or Estragole. Rev Ind Santander, 41(3): 287-294.

Naeini A, Ziglari T, Shokri K, Khosravi A, 2010. Assessment of growthinhibiting effect of some plant essential oils on different Fusarium isolates. Mycol Medicale, 20(3): 174-178.

Olmedo R, Nepote V, Grosso NR, 2014. Antioxidant activity of fractions from oregano essential oils obtained by molecular distillation. Food Chem, 156: 212-219.

Omar J, Alonso I, Olivares M, Vallejo A, Etxebarria N, 2012. Optimization of comprehensive two-dimensional gas-chromatography $(\mathrm{GC} \times \mathrm{GC})$ mass spectrometry for the determination of essential oils. Talanta, 88: 145-151.

Ortega L, Rodriguez-Garcia I, Silva-Espinoza BA, Ayala-Zavala JF, 2016. Oregano (Origanum spp.) Oils, Essential Oils in Food Preservation, Flavor and Safety, pp. 625-631.

Pandey AK, Singh P, Tripathi NN, 2014. Chemistry and bioactivities of essential oils of some Ocimum species: an overview. Asian Pac J Trop Biomed, 4(9): 682-694.

Prior RL, Wu X, Schaich K, 2005. Standardized methods for the determination of antioxidant capacity and phenolics in foods and dietary supplements. J Agric Food Chem, 53(10): 4290-4302.

Silva-Flores PG, Galindo-Rodríguez SA, Pérez-López LA, AlvarezRomán R, 2017. Free and encapsulated essential oils as potential antioxidants in skin. Rev Mex Cienc Farm 48(2): 7-15.

Stefanovic S, Spiric D, Petronijevic R, Trailovic JN, Milicevic D, Nikolic D, Jankovic S, 2015. Comparison of two analytical methods (ELISA and LC-MS/MS) for determination of Aflatoxin B1 in corn and Aflatoxin M1 in milk. Procedia Food Sci, 5: 270-273.

Tapiero T, Soleno-Wilche, R; Corrales G, 2016. Combined effect of essential oils on vacuum- packed pork ribs conservation. Rev Agron la Univ Nac Colomb, 1: S866-S868.

Torrenengra AME, 2014. Evaluation of the antioxidant activity of the foliar essential oil extracted from oregano species (Origanum vulgare), oregano "White border" (Origanum vulgare ssp) and oreganite (Lippia alba mill) cultivated in the northern area of the department of Boliv. Universidad Nacional de Colombia - Universidad de Cartagena.
Vaioa C, Di Vaio C, Graziani G, Gaspari A, Scaglione G, Nocerino S, Ritieni A, 2010. Essential oils content and antioxidant properties of peel ethanol extract in 18 lemon cultivars. Sci Hortic (Amsterdam), 126: 50-55.

Zeng QH, Zeng QH, Zhao JB, Wang JJ, Zhang XW, Jiang JG, 2016. Comparative extraction processes, volatile compounds analysis and antioxidant activities of essential oils from Cirsium japonicum Fisch. ex DC and Cirsium setosum (Willd.) M. Bieb. LWT - Food Sci Technol, 68: 595-605.

Citation: Tapiero J, Salamanca G, Marín C, 2019. Analysis of volatile compounds and antioxidant activity of the essential oil of Oregano (Origanum vulgare L.). Adv Med Plant Res, 7(2): 54-60. 